\section{Oil disquiet at Santa Barbara}

Los Angeles

THE University of California at Santa Barbara (UCSB) is about to build 65 new faculty houses with spectacular views of the Pacific Ocean, nearby beachfront and modern conveniences, all within walking distance of campus. But university officials are worried that professors attracted to their seaside campus might be disappointed. The reason is that UCSB has rich oil deposits in its front yard. An oil company plans to erect two giant drilling platforms in shallow water only a mile and a half away from campus and from the new faculty housing. And it is not just the view that is being threatened: the university's marine scientists fear that a marine studypreserve in the waters off campus could be harmed by the mud produced in drilling.

UCSB chancellor Robert A. Huttenback seems reconciled to development of some kind, but says that the way it is done may be crucial. "If the air gets mucked up, the research environment could be ruined. The university could lose its appeal to students

and faculty."

Everyone agrees the project will go ahead. The state of California is eager to lease the offshore tract to Atlantic Richfield (Arco), a Los Angeles-based oil company, because the state expects to earn between $\$ 600,000$ and $\$ 1$ million a day when the facility reaches peak production in 1992 .

Arco has held its lease on the tract since 1945; but has only recently discovered the major new oil deposits. The Santa Barbara Channel and nearby Santa Maria Basin, most of which are under federal control, are expected to become the second largest offshore oil development in the Western hemisphere. Six other oil companies hold leases off Santa Barbara's coast but only Arco's is in the university's front yard.

The project calls for two double platforms to rise about 14 stories above the ocean floor and will produce from 80,000 to 500,000 barrels of oil a day. Plans for treating and transporting the crude oil and natural gas are under discussion.

On campus, likely winners include the

\title{
Franco-Japanese voyage
}

\section{Hitch mars start for Nadir}

\section{Tokyo}

No sooner had the French research vessel Nadir, with the deep-sea submersible Nautile riding piggy-back, set sail on 1 June on the second phase of the FrancoJapanese deep-sea project Kaiko than mishap struck with an accident that injured two French crewmen, one of them seriously. They were struck by flying metal from a ring that broke when testing the crane used to lower Nautile from the mother ship. Two relief crew are being flown out to Japan. Once they are on board, the Nadir will immediately set sail again on its threeleg cruise to explore the plate boundaries running along the deep-sea troughs and trenches off the coast of Japan.

The accident aboard the Nadir must add to the worries of Kazuo Kobayashi, Japanese co-director of the project, whose worst nightmare is that the Nautile will collide with a ship when she surfaces. The seas off the Pacific coast of Japan are crisscrossed by some of the busiest shipping lanes in the world and, near the junction of the Japan and Kuril trenches, where the cold southward-flowing Oyashio current meets warm air masses from the south, fog is frequent. As the Nautile has a cruising speed of only one knot, extensive surveys of currents in the study areas have been carried out before the survey to avoid unnecessary "drift" of the submersible during its planned two-hour descent to 6,000 $\mathrm{m}$. Transponders placed on the bottom will allow navigation with pinpoint accuracy and the submersible can be directed by telephone to spots of interest by the mother ship. Time on the bottom will be about five hours at $6,000 \mathrm{~m}$ during which the submersible can traverse about $9 \mathrm{~km}$ of sea floor. The three-man submersible will carry only one scientist at a time, so French and Japanese researchers will take turns to descend.

The temporarily delayed voyage is due to finish on 19 June after exploring the Tenryu Canyon and Zenisu Ridge which flank the Nankai Trough - a sedimentfilled basin that straddles the boundary between the Eurasian plate on which Japan rides and the subducting Philippine plate which plunges beneath Japan.

The second leg, from 22 June to 10 July, will traverse the Suruga and Sagami troughs that cut into the Japanese mainland at the leading edge of the subducting Philippine plate. Nautile will then investigate Dai-ichi Kashima Kaizan, a Fuji-sized seamount that is being sliced and swallowed up by the Japan Trench (Nature 313, 433; 1985). On the final leg, from 13 July to I August, a seamount in a similar predicament will be investigated at the junction of the Japan and Kuril trenches, and it is hoped to make the deepest dive to nearly $6,000 \mathrm{~m}$.

Nautile may also find subduction-zone analogues of the "vent communities" of giant tube worms and clams found at spreading centres, but here associated with cold seeps of methane rather than hot sulphur-rich waters (see Nature 313, 339; 1985). No biologists, however, will participate in the dives, which will be manned by geophysicists, geologists and geochemists.

David Swinbanks structural and ocean engineers who will participate in designing new offshore platforms. Most worried are the marine scientists. Those affected by the project bring in over $\$ 5$ million a year to the university in outside grants.

Aquatic biology has 1,450 undergraduate majors and 148 graduate students, making it the nation's largest marine sciences

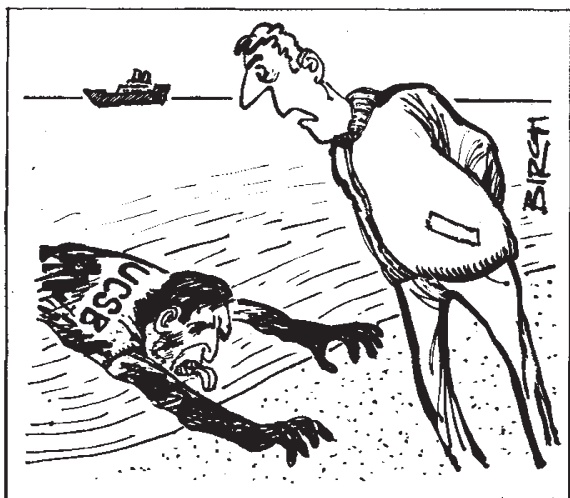

Not another oll-slicked Marine Blologist!

programme for undergraduates. Pioneering work has been done on abalone culture, bioluminescence, kelp reproduction and sediment transport. A specialized seawater system pumps water into laboratories and classrooms.

Because of their stake in the waters off campus, UCSB scientists are trying to convince state authorities that the usual legal requirements for protecting the environment are not enough to safeguard the area for research purposes.

Will toxic drilling muds damage the marine habitat? A preliminary study, paid for by the chancellor's office, indicates that such muds are detrimental to juvenile but not adult organisms. There is worry the muds might kill young abalone and other species and also foul the seawater intake system. To quell such fears, Arco has said it might barge drilling wastes ashore to avoid contamination.

The university also fears there will be a housing shortage caused by the influx of workers. Rents are already high and the school will have to increase financial aid so that students can afford to live nearby.

But aesthetic concerns top the list. The campus is only two miles from the Santa Barbara airport and some professors are already bothered by helicopters taking off every 15 minutes or so as part of the overall oil development taking place in the region. Oil platforms, no matter how well built, strike many people as ugly. And their operations do sometimes emit foul-smelling odours that even now (from other oil rigs seven or more miles offshore) waft across campus a couple of times a month.

The views of the university are important to Arco, according to Robert Flaherty, a company vice-president. Nobody in the industry would produce oil and gas at the price of damaging UCSB's educational and research activities, he says. "We can't see the remotest possibility of these terrible effects." 